\title{
University Human Resource Management Problems and Countermeasures
}

\author{
Xin Yan \\ Department of Human Resources \\ Jinan University \\ Guangzhou,Guangdong,510632 China
}

\author{
Yifan $\mathrm{CaO}^{*}$ \\ School of Journalism \& Communication \\ Jinan University \\ Guangzhou,Guangdong,510632 China
}

\author{
Feng Tong* \\ Department of Human Resources \\ Jinan University \\ Guangzhou,Guangdong,510632 China \\ *Corresponding author.
}

\begin{abstract}
Human resources are the primary resources of colleges and universities; good human resource management is the key to achieving sustainable development of university initiatives. College human resources are scarce characteristics and competitive and there is a major problem uneven level of human resource management and management measures in place, such as human resource management universities. To get rid of the University Human Resource Management crux, we must change our concepts, building mechanism, performance evaluation measures taken gradual reform and innovation.
\end{abstract}

Keywords- Human Resource Management College or University Questions Measures

\section{INTRODUCTION}

With the development of higher education, human resources are increasingly being seen as the first university resources, the concept and meaning of human resources changs along with economic and social development. Modern management guru Peter Drucker thinks human resources are not currently possess qualities than other resources that, namely "coordination, integration ability, judgment and imagination," which is a special kind of resource, must be an effective incentive mechanism to exploitation, and bring economic value to the organization is visible, is the general term for a series about people of all abilities.

The university is the cradle of personnel training, knowledge innovation hotbed. University teachers are the most important human resource, the discoverer of talent, knowledge disseminators and creators. The following is University Human Resources major exhibit characteristics.

Human resource is the human body, human resource development and utility is dependent on talent acquisition itself, the lack of essential human right, human resources will be gone. Good human resources depends on the quality of in talent selection, in the matter of personnel training and development, as well as the loyalty of talent.

Active asset, not arbitrarily control and is inalienable and incentive. HR control in individuals themselves, other people or organizations can not be denied, nor arbitrarily confiscated, their only incentive to be efficient in order to make individual human resources to achieve maximum effectiveness. Through timely and effective incentive, initiative for human resources or organizational unit can create more efficiency and value.

Timeliness and renew ability. University Human Resources is a resource of knowledge and skill-intensive, as the main control of human resources for the pursuit of spiritual values, self-worth is often more intense impulses and desires. Human resources are an intangible asset that can create more social value, increasing organizational efficiency and achieve common rapid development organizations and individuals.

\section{THE NECESSITY OF UNIVERSITY HUMAN RESOURCES MANAGEMENT REFORM}

The 21 st century is the knowledge economy era. With the development of market economy, competition in the industry is becoming increasingly fierce. Competition in the industry is ultimately the talent competition; to strengthen the effective management of talent is the best way to gain a competitive advantage in various industries, optimizing the allocation of resources. Colleges and universities is not only a staging ground for talent, but talent exporter, its human resource management situation will determine the quality of the overall strength of its development and personnel training, and only continue to strengthen the human resources management reform and innovation, in order to break the current management difficulties, achieve universities sustainable leaps and bounds. Human resource management and innovation is one of the important indicators of university work of the school, to a certain extent, determine the direction of development and the overall strength of the university. Reform of the existing human resources management is very important to a new concept of 
innovation University Human Resource Management, a new method of strategic significance to run toward modernization, the world and the future of higher education, and trained personnel useful,.

Human Resource Management Reform can create breakthrough limitations of traditional personnel management environment; accelerate the pace from the traditional personnel management to modern human resources management transition. Human resources reform and innovation is to get rid of outdated personnel management system in the past, university human resource management new mechanisms and new methods of innovation, from the traditional personnel management transformed into positions of management, human resources management to enhance the overall development of the university to relate strategic height.

Human Resource Management Reform can effectively meet the current educational system, to achieve leapfrog development of higher education, offer more highly qualified personnel for China's modernization. There are a range of human resource management issues in colleges and universities of our country, a serious impediment to the development of the training and universities. Those factors which do not favor change through personnel training and university development, innovation and new ways of human resource management; human resource management can be an effective solution to the current problems.

\section{HUMAN RESOURCE MANAGEMENT PROBLEMS ON COLlEGE}

Colleges and universities are staging of human resources, with much high-quality talent, how to strengthen the management of these human resources is a common problem faced by each of the universities. Human resource management and human resource management universities has similarities, but also some differences. University Human Resources major creation of knowledge and ideas, cultivate social needs more human resources; and corporate human resources to create the main product or service. It is to create value for the university human resources utilization or practices. However, both the management of human resources to maximize the play emphasizes its value, to create more effective, so there are some similarities between.

Currently, human resources management level of our universities is uneven, some human resource management needs of colleges and universities are not well adapted university development. Especially in the era of knowledge economy, university human resource management is related to the level of university development competitiveness and vitality. Based on the current human resource management and many other ills, we must continue to strengthen the human resources management reform and innovation. By analyzing the current situation of China's major universities human resource management, the main problems are as follows:

More personnel management tends to traditional transactional stage; there is no upgrade to a strategic level. Human Resource Management in College probably gone through three stages: the transactional execution phase, which is the so-called administrative power mode, the personnel management by way of command, which is a product of the planned economy era; system planning stage, through the establishment of a series of regulations system to restrain human behavior, configure the use of resources, because of the lack of systematic, making human resource management more tend trivia management; strategic planning stage, the overall situation from the organization, and consider a variety of resources and reasonable arrangements for effective configuration, strategic planning, system planning and operations for effective implementation of the three unified, in order to maximize the effectiveness of human resources play.

Interest-oriented human resource management deviate teaching than scientific research. So many teachers regard the main focus on research, neglect teaching, leading to today's college students the knowledge content and quality is getting worse.

Sided superstition "quantitative management", the assessment "one size fits all" quite serious. Human Resource Management is a comprehensive management university teachers, how to strengthen the management of teachers, good teachers to maximize the use of resources to achieve long-term development is a key element of university. Major colleges and universities in human resource management, often highlighting the number of published papers and teacher level by the so-called "quantitative management" to the welfare of teacher's salary distribution and job classification. Whether the individual teachers are good at research or good at teaching, research must have certain outputs, the evaluation mechanism of this "one size fits all" model and results than the process of teaching inevitably dampen the enthusiasm, so many teachers are devoted to research, the blind pursuit number of research papers, leading to quick success, fraud, shoddy.

University Human Resources Chief of evaluation bias, lack of participation of teachers in the subject. Effective human resource evaluation mechanism can pass pressure, the pay and benefits management, job adjustments and achieve the organization's mission and goals. From the current practice of each university term of human resource evaluation, basically by school personnel department in accordance with the pre-designed quantization table itemized evaluation score more tends to subjective judgment.

In short, the university human resources are the primary resources, good human resource management is one of the strategic elements to achieve long-term development support universities. Therefore, we must as soon as change the major universities in the re-introduction of the introduction of talent, light train; heavy in terms of scientific research personnel evaluation, light teaching; heavy result, light process; heavy quantity, the quality of light in the teaching status quo with regard to remuneration paid, and strive to create university Human resources Management for relaxed environment. 


\section{RELATED INITIATIVES UNIVERSITY HUMAN RESOURCE MANAGEMENT}

A. Innovative new concept of human resource management, and achieve "people-oriented" changes.

Traditional personnel management only university teacher hiring, evaluation of incentive, appointment and removal of the deployment and management of wages and benefits for job content, it is administrative things work, are the "thing" as the center. The human resource management is that the "people" as the center, university human resources management is all work to serve the teaching and research, in order to enhance the enthusiasm of teachers' work, initiative, creativity and work of mission, a sense of accomplishment, as well as the organization the sense of belonging. To focus on the development of human resources, and committed to the rational use of manpower, to achieve scientific and human resource management as soon as possible, standardization and standardization.

\section{B. The correct interest-oriented human resource management universities, teaching and research to achieve double harvest.}

Human resource management systems and policies can affect business operations throughout the university, guiding teacher behavior. University teacher's work including leading teaching and research work, but how to balance both the allocation of resources is a systemic problem. No research work, teaching content becomes concentrated on updating old single, knowledge requires constant; and the purpose of the study is to teaching, using the latest knowledge to teach more students, in order to create new knowledge, but good social practice guidance. By optimizing resources and innovative teaching and research work on the evaluation mechanism to guide teachers a reasonable position, play to their advantages of resources to achieve the configuration.

\section{Improve the human resource evaluation mechanism, establishes a comprehensive work and job analysis model.}

Job analysis is the basis of university human resource management, improving the distribution system has an important role in the assessment. It is the basis for the reform of university human resource management. It refers to the prior evaluation of human resources for each individual work and then set the evaluation index system based on the analysis results, and reasonable weight distribution. The job positions analysis is based on the value of the university, such as professor positions, according to the designed value analysis job responsibilities and job index system to evaluate their work a sense of responsibility, learning experience, innovation and other factors and sub-factors, analyze and calculate the formation of the score, and so come to value analysis and value of each job, thus forming a complete job evaluation system.

\section{The reform of outdated institutional mechanisms to implement competition.}

For colleges and universities strong administrative color ills, we must innovate university human resource management mechanism, to the Chief, to achieve selection, employment and scientific managing people, get rid of faculty tenure status. Appointment is an effective way to solve San Yong lazy college teachers, and staff can intensify the passion to work actively to promote orderly competition. Institutional mechanisms through human resources management reform, the establishment of a "staff can be hired, promoted or demoted position, the treatment can be high-energy low," the new competitive incentives.

\section{E. To optimize compensation management, enhance the cultural incentive effect.}

Pay and benefits is a matter of common concern to every service staff, as well as encourage physical force staff to work hard. Scientific and reasonable salary distribution scheme designed to help colleges and universities better human resource management. The management of generalized salary including health pay (wages, benefits, etc.) and incentive compensation (honors, postgraduate opportunities) those two parts. On the one hand, relatively stable and can be dynamically adjusted with the economic and social development of the health of faculty salaries can give some job security, and enhance the sense of belonging and passion for the organization for future work; on the other hand, should increase the incentive efforts to pay, based on the analysis in order to work reasonably determine salary levels of staff in different positions, and achieve dynamic adjustment of individual pay levels, promote the rational flow of teachers, optimize human resources, improve the remuneration incentive effects. In addition, teachers can be designed with differentiated incentive welfare content based on the individual needs of different universities, designed with differentiated incentive welfare content. For example, the goal to complete the work by teachers to choose welfare programs to meet the welfare needs of the teachers have differentiated demand, made good incentive effects.

\section{F. Human resource management to the administration of universities, innovation and democratic participation mechanism construction.}

Universities is unlike college-governmental organizations, all of its work is to serve the teaching, research and student management, human resources management must reflect the degree of democracy, eliminate excessive executive of color, to achieve self-management of university teachers. By giving different jobs teachers set goals and corresponding evaluation methods and benefits case, the teacher autonomy arrangements for the content of their work and the pace of work, to avoid excessive administrative chores interference. 


\section{CONCLUSIONS}

Promoting human resources reform and innovation of college should put human resources as the most important resource, the human resource management system strategically positioned as a key factor in school quality, scale and efficiency of coordinated development, and around the school's educational goals, rational planning optimize the allocation of human resource structure, make use full benefits of college human resources. In short, in the fierce competition in the 21 st century to keep the exuberant vitality of universities, colleges and universities must deepen human resource management, human resources management reform and promote innovation.

\section{ACKNOWLEDGEMENTS}

[Grant] This article is the year 2013 Overseas Chinese Affairs Office of the State Council project "Research on Public cultural diplomacy Horizon evacuation emergency management mechanism" (item number: GQBQ2013017) and the Overseas Chinese Affairs Office of the State Council Overseas Chinese Affairs 2014 theoretical research base in Guangdong, Guangdong Overseas Chinese Affairs Center for Theoretical Study Project "public diplomacy guided sight Guangdong Overseas Chinese nationals legitimate business, establish a new image of civilization research "(project number: GDQW201404) stage research, but by 2013, Guangdong Province, education and scientific research," five "project" implementation of Guangdong college leaders ask Guangdong propaganda and ideological and cultural research personnel training mechanism "(: XCWHRCZXSK2013-17 item number);:" Guangdong Provincial Party Committee propaganda Department research topics in 2013 (2013JK023 item Number) "Building collaborative innovation sight attributed accountability and Construction the project funding;

\section{References}

[1] Hideki Chi et al: Performance Assessment in Universities of our problems and countermeasures [J] Beijing Institute of Machinery, 2005 (9)

[2] Jiang Jianhong: Human resource properties and Faculty of Management [J]. Hangzhou Institute of Electronics Industry, 2002(4).

[3] Guo Wengang such as: domestic exploration and research teacher evaluation system [J] Education Theory and Practice, 2007 (9).

[4] Jiang Pingdeng: College Personnel Management to the strategic management of a new stage $[\mathrm{J}]$ modern university education, 2002 (4).

[5] ZhengWenli: Human Resources and Human Resource Management feature universities [J] Science of Science and Management, 2006 (9). 